\title{
The Application Of E-MTBS To Increase The Quality Of Midwife Service In Giving Midwifery Care For Under Five Years Old Toddler
}

\author{
Muhasshanah*, Neny Yuli Susanti \\ Faculty of Science and Technology, Ibrahimy University, Sukorejo, Situbondo, Indonesia \\ *muhasshanah@ibrahimy.ac.id
}

\begin{abstract}
The Integrated Management of Sick Toddler (Manajemen Terpadu Balita Sakit or MTBS) is an intervention program which contains detailed explanation about the disease handling for toddler (under five years old). This program is one of the government's efforts to reduce infant mortality rate. The infant mortality rate has been globally increased in 2012 to 2016. Most of sick toddler cases found in Situbondo regency are dealing with dengue fever and pneumonia, especially in Banyuputih Public Health Center area. One of the approaches to reduce the infant mortality rate is to consistently fill the MTBS format. However, due to limited manpower and the workload, medical personnel especially midwife could not optimally fill out the MTBS, so that toddler diseases could not be detected early. It is because the filling format and the reporting system of MTBS are not user friendly. It is done by filling the MTBS sheet and adjusts it with MTBS regulation, which results to medical personnel's unwillingness in filling the sheet. The objective of this research is to develop MTBS implementation by using Information Technology System, in order to increase the quality of midwife service in giving midwifery care and reduce the infant mortality rate in Banyuputih Public Health Center area. This research used System Development Method; started from data preparation, design, system creation and implementation, ended by monitoring and system evaluation. This research generated a product in the form of information system called e-MTBS. It contains the list of various diseases along with the treatments which help and simplify medical personnel's duty in data recording. It is expected to help early detection of toddler disease, and improve the quality of midwife service, in order to reduce the infant mortality rate in Banyuputih area.
\end{abstract}

Keywords: MTBS, Midwife, Science, Submission

Received September 17, 2020; Revised September 30, 2020; Accepted October 23, 2020 


\section{STRADA Jurnal Ilmiah Kesehatan}

DOI: $10.30994 /$ sjik.v9i2.485

ISSN: 2252-3847 (print); 2614-350X (online)

Vol.9 No.2 November 2020 Page.1415-1421

\section{BACKGROUND}

Millennium Development Goals program in 2015 was to reduce toddler, infant and neonatal mortality rate. In children health development, the effort to reduce toddler, infant, and neonatal mortality has been done in various ways, such as health services access and health service quality development program (Depkes RI, 2017). The Integrated Management of Sick Toddler (MTBS) is an intervention program containing detailed explanation about the disease handling for toddler under five years old. The MTBS case management process is applied to sick toddler between 2 months old and 5 years old; and it has been expanded for 1 day old to 2 months old infant both the sick (MTBS) and healthy (MTBM) ones.

According to Indonesian health profile, the infant mortality rate in 2017 was 32 per 1000 live birth. In East Java, the mortality rate was 23 per 1000 live birth, while in Situbondo regency, the mortality rate in 2016 was higher than 2015 , from $10.7 \%$ to $11.8 \%$, with the cause of diarrhea, pneumonia, dengue fever, and febrile seizure. The highest case finding of dengue fever in Banyuputih Health Center was approximately 28 cases during 2018 , and approximately 20 cases of pneumonia. One of the approaches to reduce toddler and infant mortality rate is the application of MTBS.

The submission of medical personnel especially midwife in implementing the examination to sick toddler according to the existing standard become the key in MTBS implementation. The Regency Public Health Office and public health center as the executive of infant and toddler health has obligated MTBS implementation, especially in the completion of MTBS sheet. However, in real life implementation, it resulted in incomplete MTBS sheets, such as performing an infant examination without filling MTBS sheets; midwifes only filled the medical record book. In the implementation of case management process, the use of MTBS sheets and its proper completion determine the success of infant and toddler comprehensive treatments. The preliminary study shows that the reasons of MTBS incompletion are the limited midwife manpower and their hectic workload, the inconvenience of MTBS format, and the reporting system which was not user friendly. It was only available in paper-based format and require midwife to write down every single symptom and treatment step and adjust it with MTBS guide book, which resulted in medical personnel unwillingness in filling the sheet.

\section{METHODS}

A method and specific plan must be brought up to answer the existing problem. There are some approach methods which has been conducted to solve related problem. The method implementation steps are as follows:

1. Problem Identification

Problem identification is conducted in the early steps of the research by doing observation in some public health unit in Banyuputih area. In this step, researcher conducted a survey to know more and to find possible solutions for the emerging problems. The problem found was medical personnel in some public health units and public health center didn't fill the MTBS sheet. Moreover, the MTBS format filling system must be adjusted to some regulations distributed by public health office which are not user friendly. This resulted in unwillingness in filling the MTBS sheet.

After identifying problems, researcher conducted an observation by collecting required data using interview and literature review, which then MTBS Information System would be made and called as e-MTBS. 


\section{STRADA Jurnal Ilmiah Kesehatan}

DOI: $10.30994 /$ sjik.v9i2.485

ISSN: 2252-3847 (print); 2614-350X (online)

Vol.9 No.2 November 2020 Page.1415-1421

2. System Planning

After analyzing all the collected data, the next step is the planning of MTBS information system to simplify midwifes duty to fill the MTBS sheet without having to adjust it and writing it down manually. MTBS planning has been adjusted with the needs and regulations in MTBS format by providing context diagram, data flow diagram, and entity relationship diagram.

3. Building a System

This step is where the PHP programming language is created to build an information system by applying all the arranged plans based on the problem analysis about MTBS sheet incompletion in Banyuputih public health.

4. Testing and Implementation

This research used analytical method with cross-sectional design. The research time was conducted from February to July 2020. The research variable was the eMTBS implementation and the enhancement of midwife knowledge and submission. The research subject was midwife in Banyuputih area, consisting 27 midwives in 9 public health units and 3 midwives in the public health center. The sample was obtained by using purposive sampling. The materials and devices used during the research were questionnaire and e-MTBS expert system. The steps of research procedures were conducting survey, system planning, building the system, and evaluation monitoring. This research analyzed the data of knowledge by using Wilcoxon Test, and using McNemar Test to analyze submission.

\section{RESULTS}

This research resulted in a generated system called e-MTBS. It's an information system created to help simplifying midwives task to fill MTBS sheet, in order to improve the midwife service in giving midwifery care for toddlers in Banyuputih public health center.

There are some menus in e-MTBS according to each user's access rights. Every midwife who works in public health unit and public health center has their own account. There are some sub-menu in the data setting menu, such as menu to process the village data, public health units, symptoms, classifications, and treatments. Data setting menu is the supporting data to produce output data which automatically processed by the system. Meanwhile in master menu, there are sub-menu to process the data of the mother, child, and the midwife. The visit and checklist of sick toddler data is inputted in Sick Toddler sub-menu in the Attendance menu.

Picture 1

The preview of toddler data options

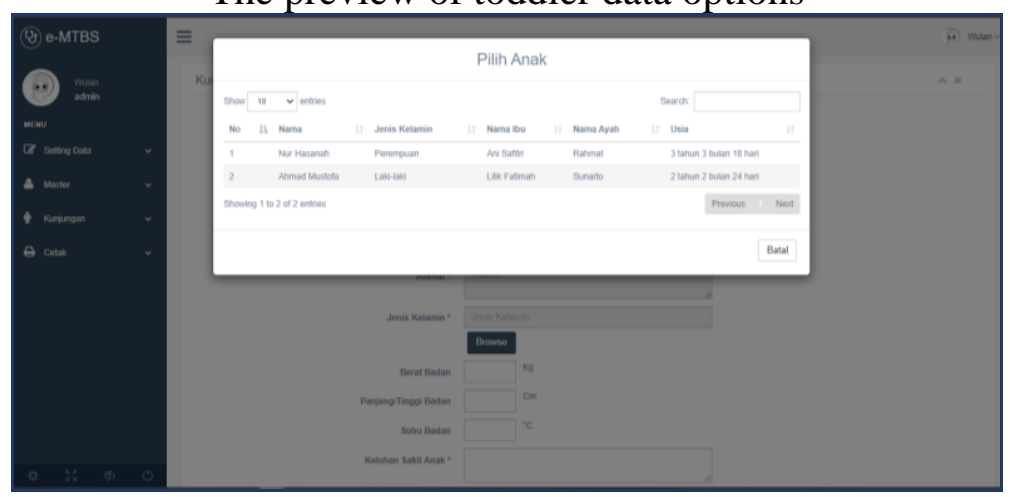




\section{STRADA Jurnal Ilmiah Kesehatan}

DOI: $10.30994 /$ sjik.v9i2.485

ISSN: 2252-3847 (print); 2614-350X (online)

Vol.9 No.2 November 2020 Page.1415-1421

Picture 1 shows the options of toddler data inputted in the toddler data master menu. Toddler data should be inputted only once in the first visit. In the next visits, midwife should choose the saved data in the database.

Picture 2

The form preview of sick toddler visit data

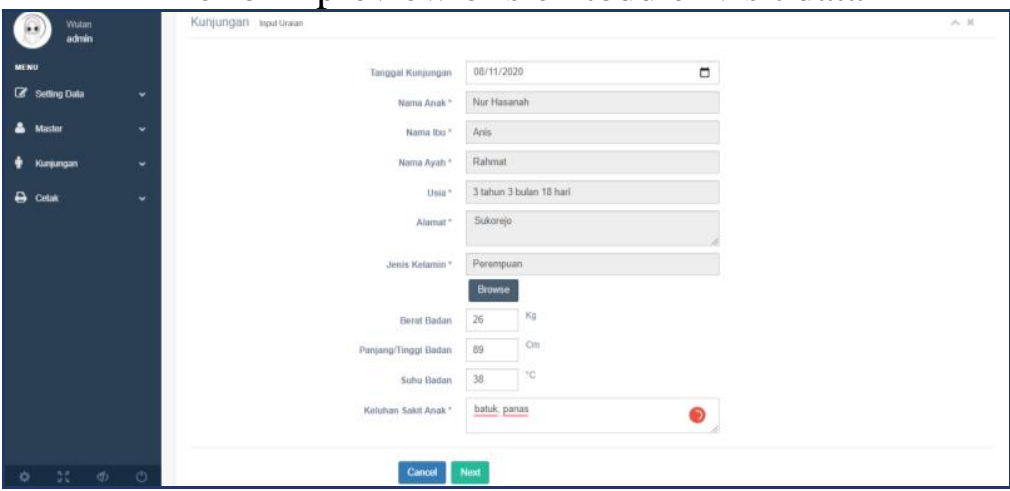

Picture 2 shows the first form preview for sick toddler visit. In this form, midwife should fill the date of the visit, toddler weight, height, temperature, and symptoms. Meanwhile, the form consisting of the toddler name, mother's name, father's name, toddler age, gender, and address would be automatically inputted from the master data. Midwife doesn't need to manually count the toddler age anymore; the system would automatically adjust it with the inputted birth date in the database.

Picture 3

The format preview and checklist of the toddler symptoms

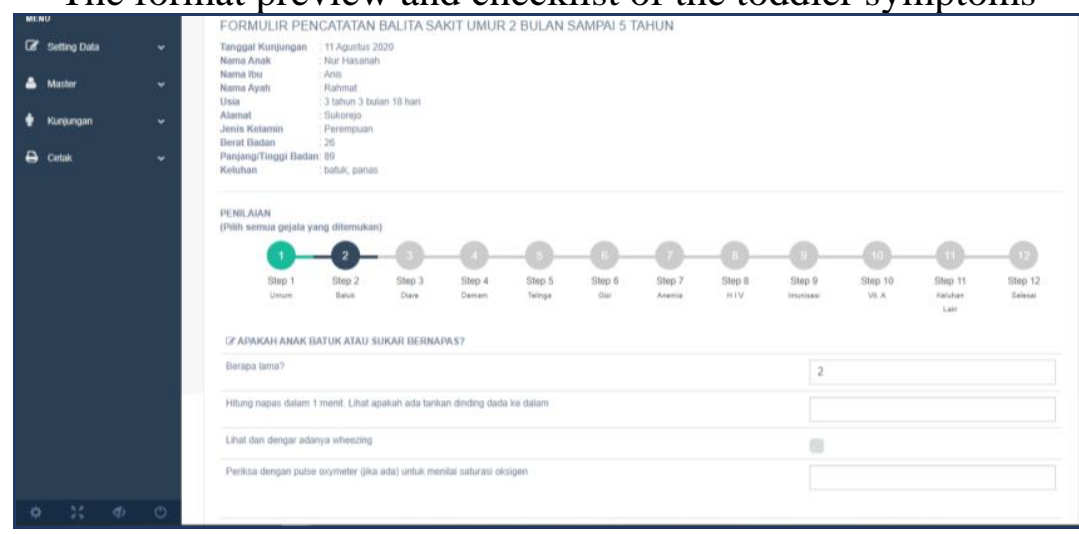

Picture 3 shows the form and checklist of toddler symptoms based on midwife anamnesis. This form would automatically load toddler data that has been previously inputted by the midwife. There are 12 steps containing 11 symptom categories which can be filled by the midwife based on the toddler disease; such as general signs, couch, fever, diarrhea, ear problem, nutrition, anemia, HIV, immunization, giving vitamin A prescription, or other needs and symptoms according to MTBS chart. Step 12 is clicking Finish button, and the automatically processed data would appear on screen, without requiring the midwife to adjust it with the checklist. The output would be in the form of the classification of the disease along with the treatment needed. 


\section{STRADA Jurnal Ilmiah Kesehatan}

DOI: $10.30994 /$ sjik.v9i2.485

ISSN: 2252-3847 (print); 2614-350X (online)

Vol.9 No.2 November 2020 Page.1415-1421

After that, e-MTBS was tested to the midwives working in Banyuputih public health. From the collected data, the respondent characteristic based on age was obtained.

Table 1

Respondent characteristic based on age

\begin{tabular}{c|c|c}
\hline Age & Number of People & Percentage \\
\hline $\mathbf{2 0 - 3 0}$ years old & 15 & $50 \%$ \\
\hline $\mathbf{3 0 - 4 0}$ years old & 10 & $33 \%$ \\
\hline$>$ 40 years old & 5 & $17 \%$ \\
\hline Total & 30 & $100 \%$ \\
\hline
\end{tabular}

The table shows that the respondents are mostly 20-30 years old. Those are the fresh graduate ages, where experiences in health care quality haven't been sufficient, especially in filling MTBS form.

Table 2

The analysis of respondents' knowledge difference before and after research

\begin{tabular}{c|c|c|c}
\hline \multirow{2}{*}{ Knowledge } & \multicolumn{3}{|c}{ Category } \\
\cline { 2 - 4 } & Good & Moderate & Less \\
\hline Pre e-MTBS & $1(3 \%)$ & $11(37 \%)$ & $18(60 \%)$ \\
\hline Post e-MTBS & $16(53 \%)$ & $10(34 \%)$ & $4(13 \%)$ \\
\hline p Value & & 0,000 \\
\hline
\end{tabular}

The table shows that there was difference in respondents' knowledge before and after the implementation of e-MTBS with the value of $p<0,000$.

Table 3

The analysis of respondents' submission difference before and after research

\begin{tabular}{c|c|c}
\hline \multirow{2}{*}{ Submission } & \multicolumn{2}{|c}{ Category } \\
\cline { 2 - 3 } & Submissive & Obstinate \\
\hline Pre e-MTBS & $10(33 \%)$ & $20(67 \%)$ \\
\hline Post e-MTBS & $26(87 \%)$ & $4(13 \%)$ \\
\hline p Value & \multicolumn{2}{|c}{0,002} \\
\hline
\end{tabular}

The table shows that there was difference in respondents' submission before and after the implementation of e-MTBS with the value of $\mathrm{p}<0.05$.

\section{DISCUSSION}

According to Notoatmojo (2014), people's knowledge is the initial trigger of their understanding, including the understanding of decision making at work. This knowledge is required in the early detection of sick toddler using MTBS. In line with Trisnawati research in 2018, the lack of medical personnel's knowledge and skill in implementing MTBS is an obstacle in MTBS completion. The respondents' knowledge difference about the importance of filling MTBS has increased significantly due to MTBS expert system which is efficiently designed and easier to understand. The effective use of MTBS makes 


\section{STRADA Jurnal Ilmiah Kesehatan}

DOI: $10.30994 /$ sjik.v9i2.485

ISSN: 2252-3847 (print); 2614-350X (online)

Vol.9 No.2 November 2020 Page.1415-1421

the respondents easier to understand its advantages and how to use it. Although the tutorial of MTBS completion has been conducted by the government, it could not reach all the existing midwives. The respondents' good knowledge would influence the accuracy in filling MTBS, so that the early detection of sick toddler can be handled faster.

Muliawan (2012) mentioned that the effort to increase health service quality is not only determined by medication but also by medical personnel submission in giving appropriate service, which in this case, is the early detection of sick toddler. According to Elisda research in 2020, good knowledge and responsiveness in filling MTBS influence the submission of MTBS management implementation. E-MTBS information system which is designed efficiently, effectively, and easy to use has made respondents' knowledge increase and more active, so it is able to improve their submission. The submission of filling MTBS is the effort in the early detection of sick toddler to get faster treatment, in order to reduce the infant mortality and disease rate, and keeping it under control.

\section{CONCLUSION}

The conducted research generated an information system called e-MTBS. The conclusion that can be drawn are as follows:

The information system was built and designed based on MTBS chart book, from the Ministry of Health, the Republic of Indonesia.

e-MTBS is able to help midwife in filling MTBS form automatically without having to count and write the data repeatedly.

e-MTBS is able to improve the midwife service in giving health care for under five years old toddler, due to automatic data processing system.

The implementation of e-MTBS influenced midwife knowledge and submission in giving qualified health care for under five years old toddler.

\section{ACKNOWLEDGEMENT}

Thanks to the Ministry of Research, Technology, and Higher Education of the Republic of Indonesia (Ristekdikti) for the support in conducting this research.

\section{REFERENCES}

Fitramaya. (2014), Asuhan Kebidanan pada Neonatus dan Bayi baru lahir, Jakarta: Rineka Cipta.

Fitriyani, Elisda. (2016), Analisa kualitas pelayanan kunjungan neonatal dengan kepatuhan bidan dalam penggunaan algoritma MTBM di Kabupaten Semarang. Jurnal Poltekes Semarang, 17(5), 104-115. 9.32465/mpk.v48h8.145

Kesehatan, Kementerian. (2015),Modul Pelayanan Balita dengan ISPA pada MTBS.

Muliawan. (2015), Faktor dominan yang mempengaruhi pelaksanaan manajemen MTBS. Healty care nursing jurnal, edisi 1 hal 57-59

Notoadmojo. (2014), Promosi kesehatan dan perilaku kesehatan, Jakarta : Rineka Cipta.

Nurmawati, Ida., Erawantini, Feby. (2018), Kebutuhan Perancangan Sistem Screening Balita Sakit Berdasarkan Klasifikasi dan Penatalasanaan MTBS, Jurnal Kesehatan, 6(3), 83-87, DOI: 10.25047/j-kes.v6i3.18

RI, Departemen Kesehatan. (2017), Dirjen Bina Kesehatan Masyarakat. Petunjuk Teknis: Penggunaan dana APBN yang dilaksanakan di Propinsi, Kabupaten/ Kota Program Upaya Kesehatan Masyarakat dan Program Perbaikan Gizi Masyarakat Tahun Anggaran 2017, Jakarta 


\section{STRADA Jurnal Ilmiah Kesehatan}

DOI: $10.30994 /$ sjik.v9i2.485

ISSN: 2252-3847 (print); 2614-350X (online)

Vol.9 No.2 November 2020 Page.1415-1421

Situbondo, Profil Dinas Kesehatan Kabupaten. (2016), Trend Angka Kematian Bayi Tahun 2012-2016 di Kabupaten Situbondo.

Suparmi., Maisya, Iram Barida., et al.(2018), Pelayanan Manajemen Terpadu Balita Sakit (MTBS) pada Puskesmas di Regional Timur Indonesia, Media Litbangkes, 28(4), 271-278, DOI: 10.22435/mpk.v28i4.125

Susilaningrum, Rekawati., Suryawati, Chriswardani.,Arso, Septo Pawelas. (2012), Pengembangan Model Peningkatan Kinerja Tenaga Keperawatan Dalam Penerapan Manajemen Terpadu Balita Sakit (MTBS) Di Surabaya, Jurnal Ners, 7(1).

Tisnawati. (2018), Pengaruh penggunaan MTBS terhadap peningkatan pengetahuan petugas di Puskesmas Blimbing Kota Padang tahun 2018. Jurnal Kesehatan Menara Ilmu, 12(8), 168-173, DOI: $10.33559 /$ mi.v12i8.880

Wardani, Adining Tyas Ambika. (2016), Analisis Penerapan Manajemen Terpadu Balita Sakit (MTBS) Terhadap Kejadian Pneumonia Balita di Puskesmas Halmahera Kota Semarang. Jurusan Ilmu Kesehatan Masyarakat Fakultas Ilmu Keolahragaan Universitas Negeri Semarang. 